\title{
The Influence of Concentration of the Antioxidants in Rosemary Extract on MCF-7 Cells
}

\author{
Ivana Andrikj \\ II. gimnazija Maribor, Maribor 2000, Slovenia
}

\begin{abstract}
In my research, I studied the antioxidant effect of extracts of various rosemary samples obtained by Soxlet extraction on MCF-7 epithelial cells. I wanted to discover which of the extracts will have the highest content of total phenols determined in vitro with the Folin-Ciocalte reagent. The results show the highest content of total phenols in the rosemary sample from North Macedonia, so I assumed that it would have the biggest effective activity on MCF-7 cells. While doing the free radical inhibition test, I came to the conclusion that the plant with the highest antioxidant content does not necessarily have the best effect on the cells at different concentrations of the extracts. I suppose that it happens because antioxidants are polar and they need to transport through cell membrane conveyors whose number is limited in the membrane, that is, more antioxidants get assembled on the conveyors and cannot go through the membrane.
\end{abstract}

Key words: Rosmarinus officinalis, anti-cancer, antioxidants, free radicals, MCF-7.

\section{Introduction}

Rosemary (Rosmarinus officinalis) is an evergreen, bushy plant that thrives in the Mediterranean. This plant is used in everyday life as a food-seasoning or as an ornamental plant. Rosemary contains $1.5 \%-2.5 \%$ essential oil [1]. Rosemary is also well known for its healing effects, for example, it improves concentration, it is highly recommended for mental exhaustion and depression, headache, as well as antimicrobial affection etc. [2].

Antioxidants destroy the reactive free radicals and do not convert them into destructive free radicals, but low-energy, long-lived free radicals that decompose themselves without harming the body. Many studies indicate the connection between the formation of free radicals (ROS, reactive oxygen compounds) and breast cancer. Desaulniers [3] discovered that carnosol (a phenolic diterpene found in rosemary) prevents the growth of tumors of the cancerous breast.

Given the high content of antioxidants in rosemary

Corresponding author: Eneko Jose Madorran Esteiro, asst. prof. in pharmachology and toxicology, preclinical biomedical researcher. and the association of antioxidants with anti-cancer properties, rosemary could be an interesting medicinal plant, as it is not difficult to be grown as well as not very demanding. I decided to research the possible anti-cancer properties of rosemary and the influence of the growing place of the plant on the antioxidant content of rosemary. I picked up and used rosemary from three different European countries (Greece, North Macedonia, Slovenia).

I asked myself the following research questions:

(1) What is the relation and difference in antioxidant content in rosemary (Rosmarinus officinalis) according to the thriving place?

Then I was interested in the antioxidative potential of rosemary within the MCF-7 cells [4] because the dangerous free radicals (ROS) are formed in those cells. So I asked another research question:

(2) What is the influence of the antioxidant content in the rosemary extract on the antioxidant potential in cancer cells of MCF-7?

The MCF-7 cancer cells, are producing many free radicals, which is exactly why these cells are very suitable for studying the effect of the antioxidants.

Hypotheses are: 
(1) Rosemary (Rosmarinus officinalis), which I have gathered in Greece on the shores of the Aegean Sea, contains the most antioxidants.

I concluded this on the basis of the characteristics of the site, because it is sunny and at the seaside and also well overhauled. Rosemary for its growth needs lots of sunlight and well drained soil with a pH between 6 and 7 [5].

(2) In preparing the ethanol extract of rosemary in the Soxhlet apparatus, 5 cycles will be sufficient.

Of the other studies, we can see that 4 extraction cycles are enough [6].

That is why I decided to make 5 cycles to see, if there are big bits after the fourth cycle.

(3) The extract with the highest content of phenols and polyphenols has the highest antioxidant potential in MCF-7 cells.

These substances destroy ROS, which means that if there are more phenolic compounds, more substances would react with ROS and consequently cause a greater effect on the cell.

\section{Theoretical Part}

Rosemary contains a large amount of carnosinic acid, which is also one of the substances that has anti-spasmodic properties. This acid dilates certain substances that trigger the growth of tumors of the breast. Approximately $80 \%$ of women have ER-positive breast cancer, which means that cancerous cells increase in response to the estrogen hormone. To block the effects of estrogen, we use tamoxifen, but it may also have many side effects. Current studies suggest that rosemary is capable of deactivating estrogen hormones by stimulating hepatic enzymes that can turn off aggressive types of estrogen. Researchers at Rutgers University evaluated the effects of $2 \%$ rosemary extract on laboratory mice and found that this diet with rosemary enhances microsomal oxidation and liver glucuronidation. Dersaulniers [3] says rosemary is a super herb because it has many good effects when it comes to fighting breast cancer, but it should not be consumed in the form of an extract, as it can also affect menstrual cycles and stimulate severe bleeding.

A part against the tumor related properties associated with rosemary may also be related to the reduction in the formation of ROS. Carnosol (phenolic diterpen) was the most effective in reducing tumor proliferation [7].

\subsection{Antioxidants and Their Activity against ROS}

Antioxidants are inhibitors of oxidative reactions. Oxidative reactions in the cells are caused by free radicals such as superoxide, peroxide radical, hydroxyl radical, etc., which can lead to damage to the heritable material of the cells (Fig. 2). Antioxidants therefore prevent oxidation or slow it down, because they can stabilize or deactivate free radicals before cells are damaged. The action of antioxidants shows the scheme in Fig. 1.

There are many substances in the foods that act as antioxidants and can prevent diseases such as heart disease, cancer, Parkinson's disease, etc. These are vitamin $\mathrm{C}, \mathrm{E}$ and $\mathrm{A}$, beta carotene and vegetable polyphenols. Some enzymes, such as catalases and

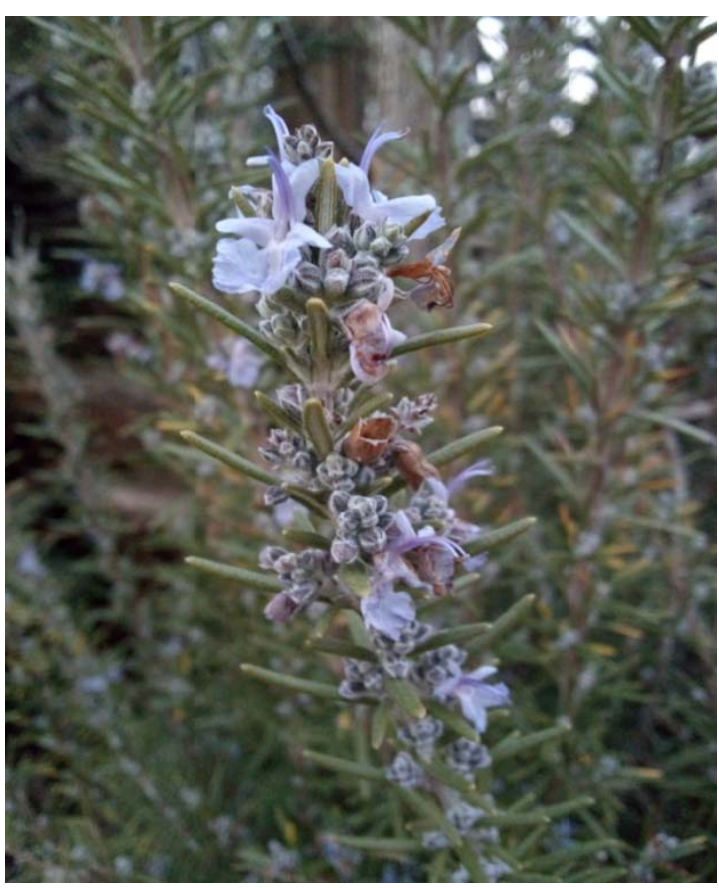

Fig. 1 Rosemary.

Source: personal. 


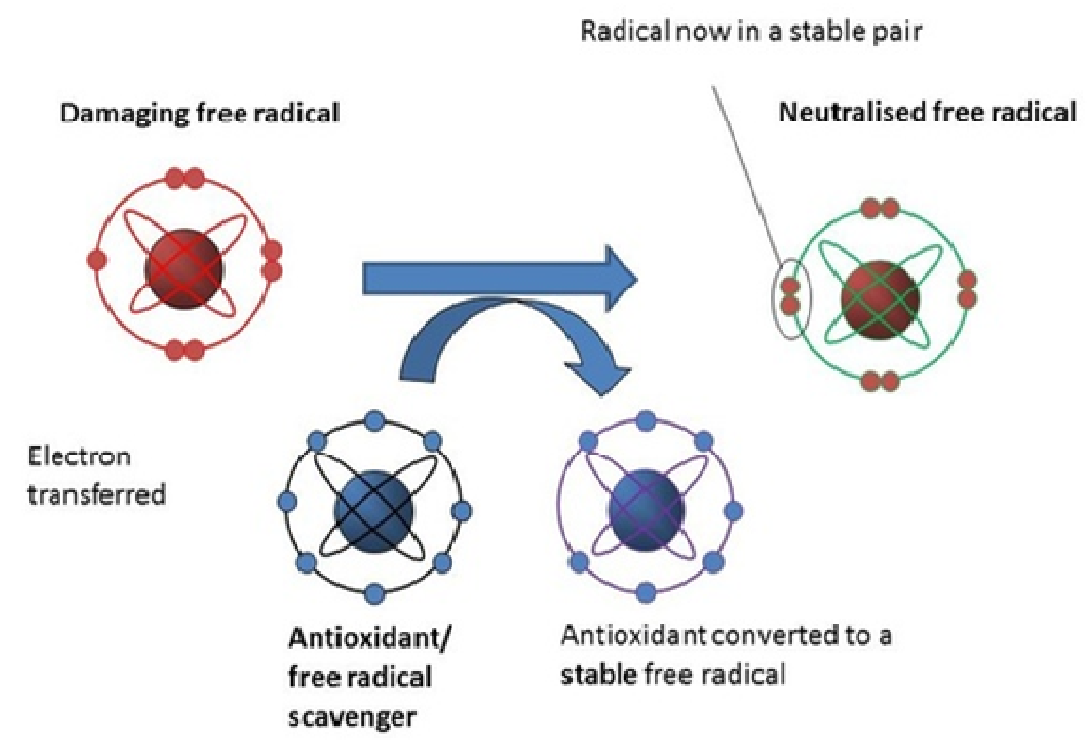

Fig. 2 How do antioxidants work?

Source:

https://www.google.com/search?q=how+antioxidants+work\&rlz=1C1GCEA_enMK829MK829\&source=lnms\&tbm=isch\&sa=X\&ve $\mathrm{d}=0$ ahUKEwie0OaqwqngAhVQDOwKHT_dD0kQ_AUIDigB\&biw=1366\&bih=657\#imgrc=6E_tDTt8xpz5oM.

superoxide dimutases, act in humans as very important antioxidants [8].

\subsection{Cell Cultivation}

Cells can be grown for various purposes, for example: testing the effects of various chemical substances on cells, for the development of artificial tissues, e.g. skin.

There are 2 different cell cultures:

Suspension culture-cells do not attach to the bottom of the flask, but freely float in the medium. When the nutrients in the medium are used, the cells are separated by centrifugation and then added to the fresh medium.

Adherent culture-cells are attached to the bottom of the flask. The advantage of the method is to simply flush out the spent medium and add fresh medium.

But also senescence can appear cellular extinction, which is a consequence of cell division. In diploid cells, it occurs in vitro after 50 duplications. Conditions for cell growth may vary, but each medium must contain the following: medium (nutrients), growth factors, gases $\left(\mathrm{O}_{2}, \mathrm{CO}_{2}\right)$. We also need to monitor $\mathrm{pH}$, osmotic pressure and temperature. The advantage of using this cell culture is the consistency and reproducibility of the results of the same cell series (in our situation MCF-7 cells (Fig. 3) [9].

MCF-7 cells are tumor cells of the breast cancer. I chose them for the research, because they are very active. There are many free radicals (ROSs) in them, and researches have already been done about the effect of rosemary on these cells [10].

MCF-7 cells were firstly isolated in 1970 from the tumors of a 69-year-old woman. Before MCF-7, it was not possible for cancer researchers to acquire a cell line of milk cells that could live for more than a few months [11].

\subsection{Preparation of the Extracts from Rosemary}

The Soxhlet extraction process comprises the following steps: a chosen amount of the dry sample is inserted into the cellulose capsule, then the capsule is inserted into the central part of the Soxhlet apparatus or, extraction chamber, which is then connected to the condenser and the boiling flask (Fig. 4). The extraction solvent is heated on the heating 

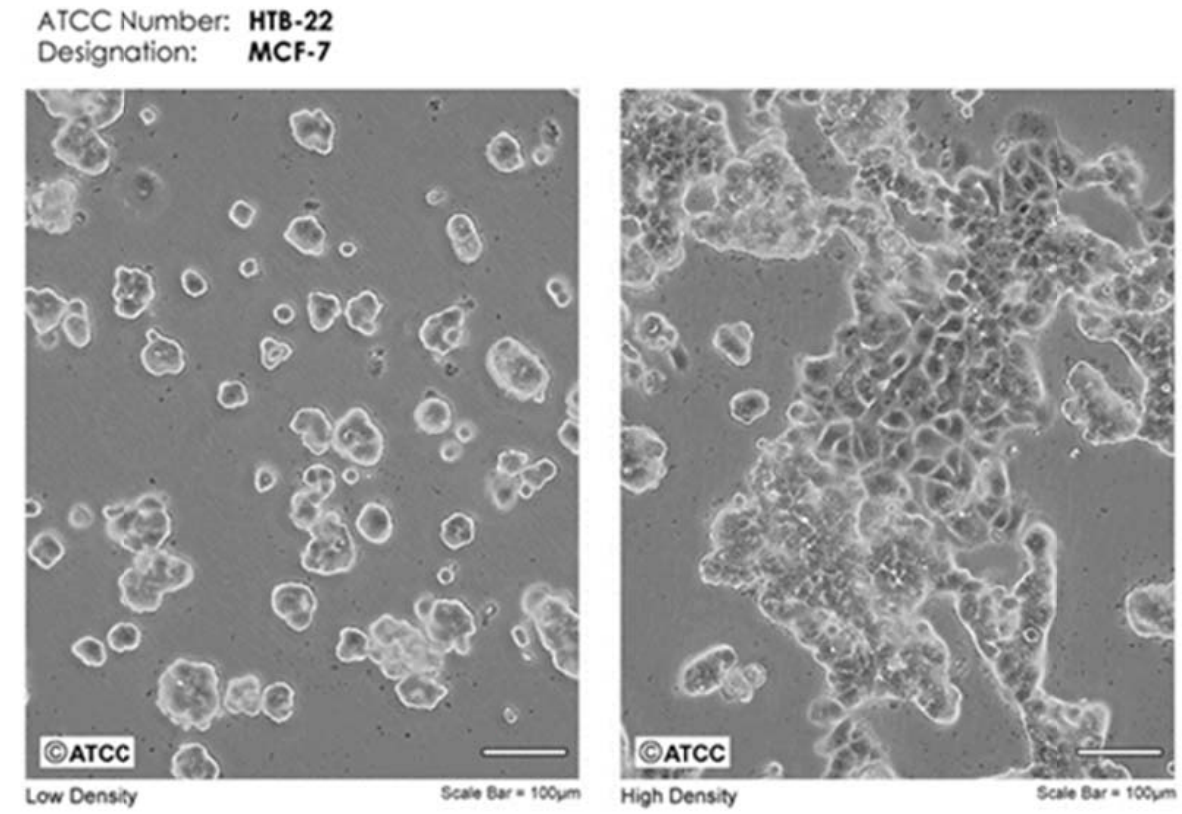

Fig. 3 MCF-7 cells.

Source: https://bit.ly/2Dgc4Xy.

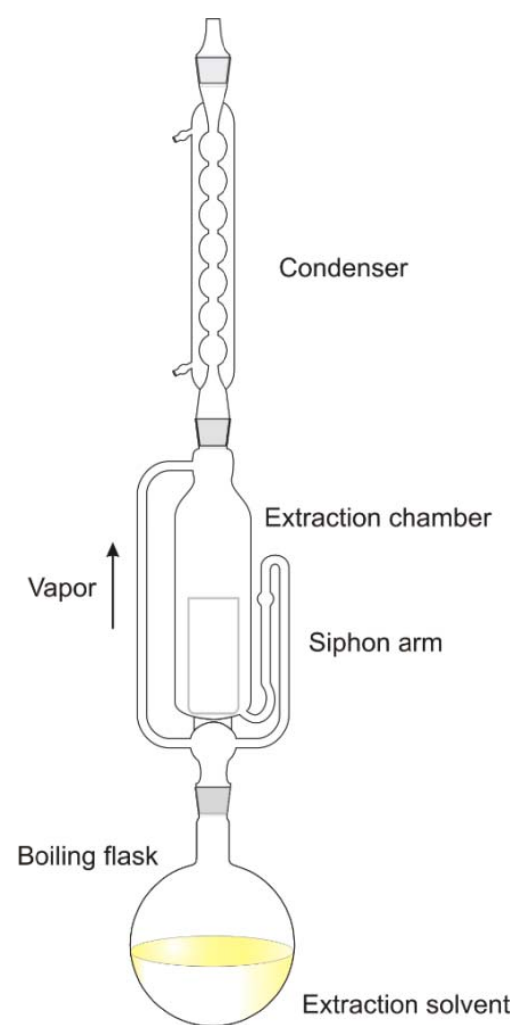

plate, and the steam is raised to the condenser where it liquids. The extraction can take from 3-6 $\mathrm{h}$ [12].

\subsection{Antioxidant Concentration Measurement}

Spectrophotometry is a method by which light absorption can be measured when passing through the sample as shown in Fig. 5. [13].

Transmittance is the fraction of incident light that the sample transmits. Absorbance is the negative logarithm of transmittance and is directly proportional to the concentration of the colored substance in the sample. The relation is described by the Beer-Lambert law:

$$
A=\varepsilon \times l \times c
$$

where $A$ represents absorbance, $\varepsilon$ is the molar absorption coefficient which is characteristic for every substance, $l$ represents the length of the light path through the solution, and $c$ is the concentration of the colored substance.

The Beer-Lambert law may be applied if the Fig. 4 Soxhlet apparatus.

Source:

https://www.google.com/search?q=soxhlet+ekstraktor\&rlz=1C 1GCEA_enMK829MK829\&source $=$ lnms\&tbm $=$ isch\&sa $=X \& v$ ed $=0$ ahUKEwixwrbfidfjAhWhxIsKHfFTAboQ_AUIESgB\&bi $\mathrm{w}=1366 \& \mathrm{bih}=657 \#$ imgrc $=$ nfGUp49mCaCOkM. following conditions are fulfilled:

- the light must be monochromatic (at one wavelength), unless the sample is able to absorb more wavelengths, 


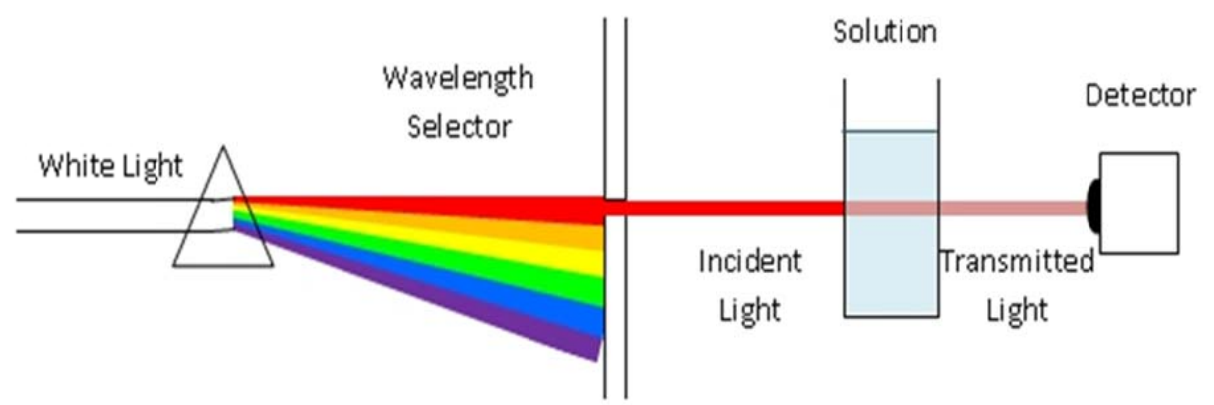

The differenœ between the incident and transmitted light

indicates the absorbanœ

Fig. 5 Spectrophotometer.

Source:

https:/www.google.com/search?q=spectrophotometry\&rlz=1C1GCEA_enMK829MK829\&source=lnms\&tbm=isch\&sa=X\&ved=0a hUKEwjq2tiUl8XfAhUuAxAIHXcHAzkQ_AUIDigB\&biw=1366\&bih=657\#imgrc=Zugane8d7HN-GM.

- the concentration of the substance must not be too high (as a rule the absorbance should not exceed 1.0) or too low (the absorbance should not be below 0.05 ).

The absorption curve is obtained by measuring the absorbance of the solution at all wavelengths. Curves can have multiple maxima. However, the analyses are performed at the wavelength of the maximum absorbance value of the absorption curve [14].

I chose the Folin-Ciocalteu reagent method to determine the antioxidant concentration because it is an accurate method for the analysis of phenols and polyphenols [15].

Folin-Ciocalteu's reagent is a mixture of phosphomolybdate and phosphovolframate. Not only the reagent reacts with phenols and polyphenols, but it also reacts with every reducing substance.

In this method as a standard compound I used gallic acid (GA), the formula shown in Fig. 6. GA. The measured results are given as the concentration equivalent to the GA equivalence method (GAE).

\subsection{DCFH-da, in Vitro Method}

The DCFH-da method is a quantitative method for measuring the oxidative potential of cells.

The DCFH-da reagent (Fig. 7) is a fluorogenic dye that measures hydroxyl, peroxyl and other ROS activities. When DCFH enters the cells, it is deacetylated by cellular esterases into a non-fluorescent compound that is subsequently oxidized by ROS to form DCF.

DCF is a fluorescent compound that can be detected with a fluorimeter at $485 \mathrm{~nm}$ and $535 \mathrm{~nm}$.<smiles>O=C(O)c1cc(O)c(O)c(O)c1</smiles>

Fig. 6 GA.

Source:

https://www.google.com/search?q=gallic+acid+formula\&rlz=1C 1GCEA_enMK829MK829\&source $=1 \mathrm{nms} \& \mathrm{tbm}=$ isch\&sa $=\mathrm{X} \& \mathrm{v}$ ed=0ahUKEwiqp8PAxangAhWEK1AKHWOMBccQ_AUIDig B\&biw $=1366 \&$ bih $=657$ \#imgrc $=$ zz9KvpzJGcoBgM.<smiles>COc1cc2c(cc1Cl)C(c1ccccc1C(=O)O)c1cc(Cl)c(OC)cc1O2</smiles>

Fig. 7 DCFH-da reagent.

Source:

https://www.google.com/search?rlz=1C1GCEA_enMK829MK $829 \&$ biw $=1366 \&$ bih $=657 \&$ tbm $=$ isch $\&$ sa $=1 \&$ ei $=$ BqVhXMbB DrGRrgSA9KXAAQ\&q=dcfh-da\&oq=dcfh-da\&gs_l=img.3.1. 0i67j013j0i2416.2317.3448..4128...0.0..0.110.645.6j1.....1...1.. gws-wiz-img.......0i30.DJrYqElQGGk\#imgrc=_lgAmDijuQl-a M. 


\section{Experimental Part}

\subsection{Material}

- Sodium carbonate decahydrate $\left(\mathrm{C}_{7} \mathrm{H}_{6} \mathrm{O}_{5}\right.$, $\left.\mathrm{Na}_{2} \mathrm{CO}_{3} \cdot 10 \mathrm{H}_{2} \mathrm{O}\right)$,

- Ethanol $\left(\mathrm{C}_{2} \mathrm{H}_{5} \mathrm{OH}\right)$,

- FC reagent [16],

- DCFH-da,

- Media DMEM/F-12 (Gibco),

DMEM/F12 uses a sodium bicarbonate buffer system and therefore requires a $10 \% \mathrm{CO}_{2}$ environment to maintain physiological $\mathrm{pH}$.

- FBS (Gibco),

- Trypsin,

- MCF-7 cells (ATTC, USA),

- Measuring flasks,

- Glasses,

- Tubes,

- Balance $\pm 0.01 \mathrm{~g}$, analytical balance $\pm 0.0001 \mathrm{~g}$,

- 3 cellulose capsules,

- Vernier Spectrophotometer [17],

- Computer with Logger Pro software,

- Micropipette with associated attachments (10-100 $\mu \mathrm{L}, 100-1,000 \mu \mathrm{L}$ (LLG Micropipette),

- Soxhlet apparatus,

- Centrifuges,

- Centrifuge (Eppendorf 5804),

- Incubator,

- Cell culture container,

- Laminarium,

- Cell Counter (Muse, Merck, USA)

- NUNC 96 panel,

- Fluorescence spectrophotometer.

\subsection{Methods}

\subsubsection{Soxhlet Extraction}

I placed $120 \mathrm{~mL}$ of $96 \%$ ethanol in the flask and inserted a cellulose capsule filled with $7.65 \mathrm{~g}$ of dried rosemary from Macedonia into the middle part of the extractor. Extraction was carried out in five cycles. At each flow I took a sample of the extract. Following the same procedure, I also prepared extracts of rosemary from Greece (Table 3) and Slovenia (Table 4).

3.2.2 Determination of Antioxidant Content of Rosemary

The antioxidant content of rosemary extracts was determined spectrophotometrically.

I used GA for the standard and also had to make a calibration curve.

I weighed $0.0500 \mathrm{~g}$ of GA in a $100 \mathrm{~mL}$ beaker and dissolved it in $20 \mathrm{~mL}$ of ethanol. I transferred the solution, quantitatively, into a $100 \mathrm{~mL}$ volumetric flask and completed filling it with ethanol to the mark. After that I diluted this stock solution to obtain 5 standards with different concentrations as shown in Table 1.

Then I prepared $7.5 \% \mathrm{Na}_{2} \mathrm{CO}_{3}$ solution by weighing $20.3 \mathrm{~g}$ of $\mathrm{Na}_{2} \mathrm{CO}_{3} \cdot 10 \mathrm{H}_{2} \mathrm{O}$ and adding $79.7 \mathrm{~mL}$ of water. I took 5 small beakers and each gave $100 \mu \mathrm{L}$ of the appropriate standard GA solution, $2.0 \mathrm{~mL}$ of $\mathrm{FC}$ reagent, and $2.0 \mathrm{~mL}$ of $7.5 \% \mathrm{Na}_{2} \mathrm{CO}_{3}$ solution. The resulting solutions were incubated for $15 \mathrm{~min}$ at $35{ }^{\circ} \mathrm{C}$. The solutions were typically colored as shown in Fig. 9.

I used Logger Pro program and spectrophotometer. I poured standard GA 5 solution into the cuvette and measured the absorbance over the entire visible spectrum. I chose the wavelength at which the maximum absorbance was $776.5 \mathrm{~nm}$. At this wavelength, I measured the absorbance of all GA standard solutions and made the calibration line shown in Fig. 11.

After the same procedure, I analyzed the extracts. I took $50 \mu \mathrm{L}$ of each extract separately and added $2.0 \mathrm{~mL}$

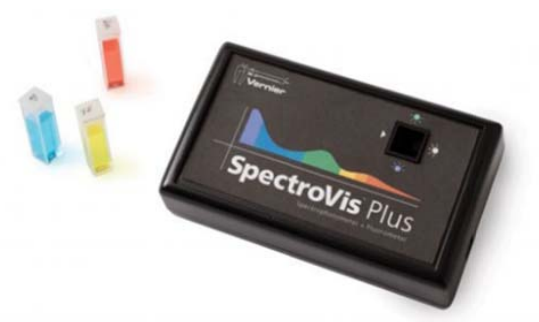

Fig. 8 Vernier vis spectrophotometer.

Source: https://www.vernier. 


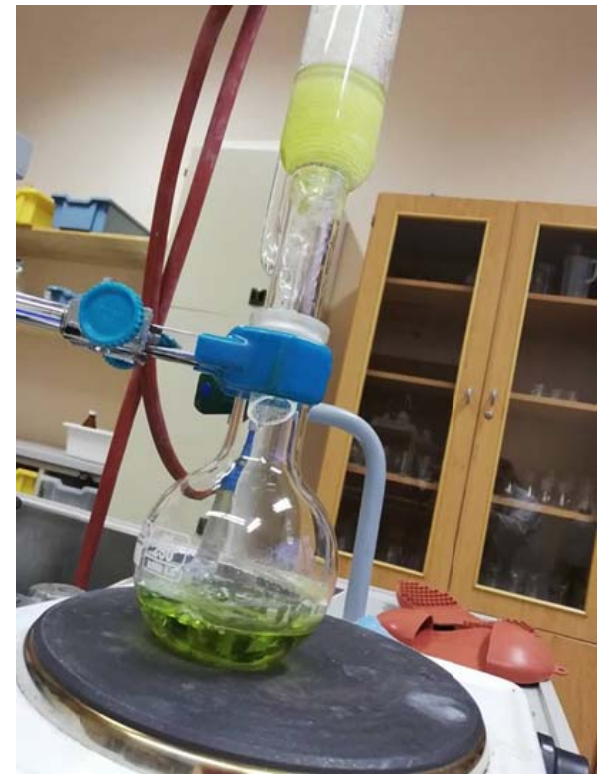

Fig. 9 Soxhlet extraction.

Source: personal.

Table 1 Standard solutions of GA.

\begin{tabular}{llll}
\hline $\begin{array}{l}\text { Standard } \\
\text { solution } \\
\text { number }\end{array}$ & $\begin{array}{l}\text { V (ethanol) } \\
(\mathrm{mL})\end{array}$ & $\mathrm{V}(\mathrm{GA})(\mathrm{mL})$ & $\gamma(\mathrm{GA})(\mathrm{g} / \mathrm{L})$ \\
\hline 1 & 0.0 & 25.0 & 0.500 \\
2 & 5.0 & 20.0 & 0.400 \\
3 & 10.0 & 15.0 & 0.300 \\
4 & 15.0 & 10.0 & 0.200 \\
5 & 20.0 & 5.0 & 0.100 \\
\hline
\end{tabular}

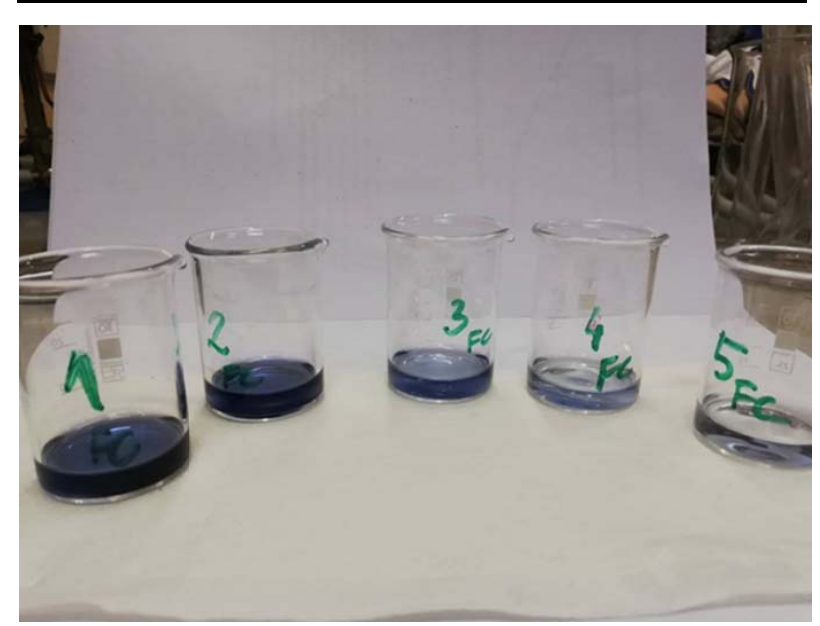

Fig. 10 Standard solutions.

Source: personal.

of FC reagent and $2.0 \mathrm{~mL}$ of $\mathrm{Na}_{2} \mathrm{CO}_{3}$ solution and incubated the resulting solution shown in Fig. 10 for 15 min. I measured the absorbance of the solution at a wavelength of $776.5 \mathrm{~nm}$ by using the spectrophotometer shown in Fig. 8. I then calculated the concentration of gallic acid equivalent (GAE) in the extract samples using the calibration line equation.

\subsubsection{Cultivation of the MCF-7 Cells}

DMEM/F-12 medium was used as cell culture nutrient. It does not contain protein, lipids or growth factors, so it is usually supplemented with $10 \%$ fetal bovine serum (FBS) [18].

FBS comes from blood obtained from bovine fetus through a closed slaughterhouse collection system and is the most widely used growth supplement for cell culture due to its high content of embryo-promoting factors $[19,20]$.

Trypsin is a proteolytic enzyme that stimulates the process of trypsinisation. This is the process by which the cells peel off from the flask they are on [21].

I performed the MCF-7 cell culture by the following procedure. I thawed the cells, which were frozen at $-81^{\circ} \mathrm{C}$, and restored them with fresh nutrient. I took the trypsin, medium and serum and heated them at $37^{\circ} \mathrm{C}$. I prepared the laminaria work surface by wiping it with ethanol to clean and disinfect it. Then I took the flask with cells and drained the liquid, so the cells remained stuck to the bottom of the flask. And $2 \mathrm{~mL}$ of trypsin was added to the cells and incubated for $5 \mathrm{~min}$ at $37^{\circ} \mathrm{C}$ an atmosphere containing $5 \% \mathrm{CO}_{2}$. During this time, the cells peeled away from the walls of the container. I transferred the contents to a centrifuge. I turned on the centrifuge and set it to $5 \mathrm{~min}$ at $330 \mathrm{RCF}$ (relative centrifugal force) and $22{ }^{\circ} \mathrm{C}$.

I added $3 \mathrm{~mL}$ of medium (DMEM/F-12) to the centrifuge, vortexed vigorously, then removed $3 \mathrm{~mL}$ of fluid. What was left $(2 \mathrm{~mL})$ was centrifuged again. After centrifugation, the liquid was poured into a beaker and the cells in the centrifuge were added $1 \mathrm{~mL}$ of serum and $9 \mathrm{~mL}$ of medium, stirred again, poured into the flask and left in the incubator.

I let the cells shown in Fig. 12 [22], grow for 1 week and repeatedly renewed the cell culture during the week as described procedure above. 


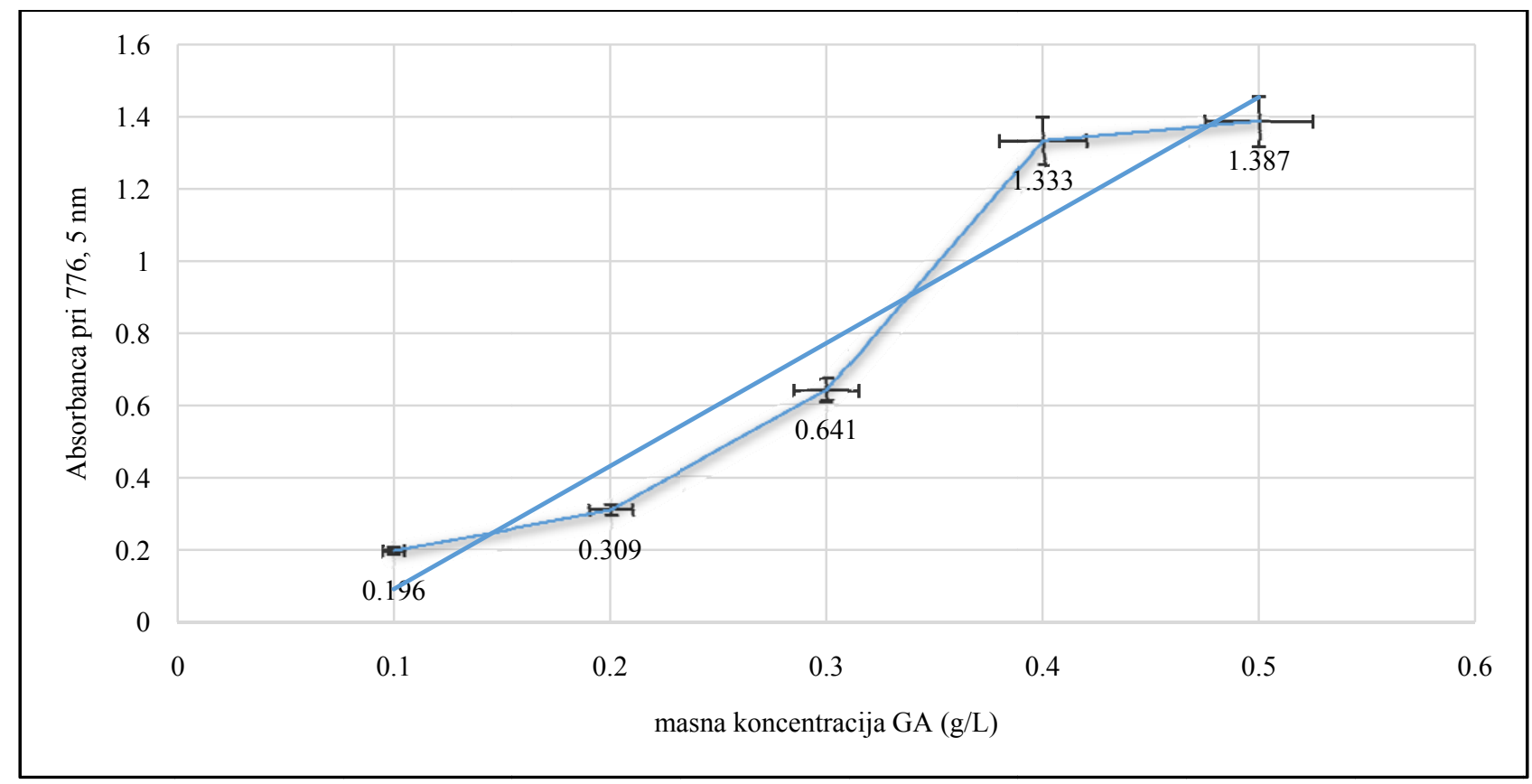

Fig. 11 Calibration line.

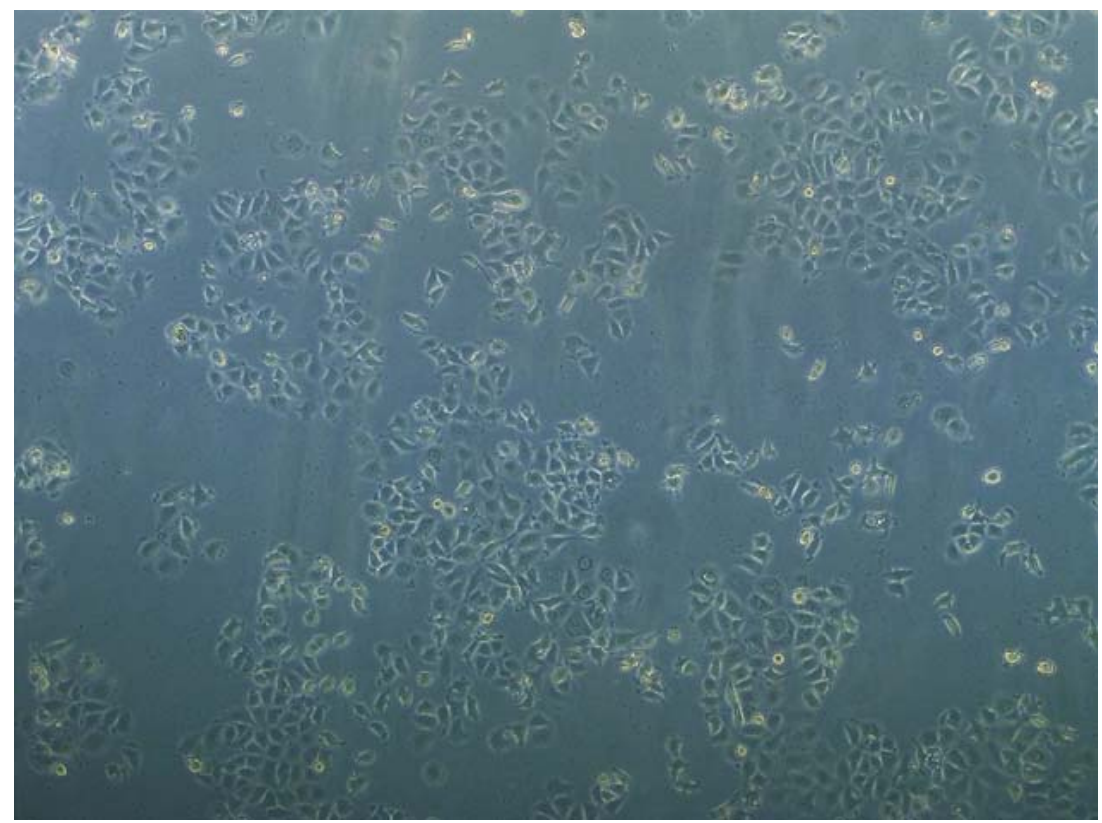

Fig. 12 Morphology of MCF-7 cells.

Source: personal.

3.2.4 Measurement of Antioxidant Potential in Cells due DCFH-da Method

- I counted the cells using a cell counter, the cell count was $5 \times 10^{6}$ cells $/ \mathrm{mL}$.

- Then I added 5 mL DMEM/F-12, stirred, and got a solution containing $10^{6}$ cells $/ \mathrm{mL}$. For further work, I needed a solution with $10^{5}$ cells $/ \mathrm{mL}$, so I diluted $1 \mathrm{~mL}$ of the stock solution to $10 \mathrm{~mL}$.

- In the NUNC 96 plate, I filled each well with 100 $\mu \mathrm{L}$ (cells and DMEM/F-12) and allowed it to incubate for $30 \mathrm{~min}$ at $37{ }^{\circ} \mathrm{C}$ and with $5 \% \mathrm{CO}_{2}$.

- Certain wells with cells serve as a control group. To these wells, I added ethanol in different concentrations and DMEM-colorless, but not rosemary extracts. 
- I added different concentrations of extracts and DMEM colorless to the wells where I was checking the effect of rosemary extracts.

Extract concentrations:

5\% of the extract contains: $100 \mu \mathrm{L}$ of extract and $1.90 \mathrm{~mL}$ of DMEM

$1 \%$ extract contains: $20 \mu \mathrm{L}$ of extract and $1.98 \mathrm{~mL}$ of DMEM.

$0.1 \%$ of the extract contains: $5 \mu \mathrm{L}$ of extract and 2 $\mathrm{mL}$ of DMEM.

- I needed to calculate the DCFH volume, so I did it the following way:

$$
\begin{array}{cc}
50 \mu \mathrm{M} \text { DCFH-da } & x \mathrm{~mL} \\
10 \times 10^{-3} \text { M DCFH-da } & 10 \mathrm{~mL} \\
x=\frac{50 \times 10^{-6} \times 10}{10 \times 10^{-3}}=50 \mu \mathrm{L} \mathrm{DCFH}-\mathrm{da}
\end{array}
$$

I dosed $50 \mu \mathrm{L}$ of DCFH-da in a centrifuge tube, added $9.95 \mathrm{~mL}$ of DMEM and mixed everything.

- After $30 \mathrm{~min}$, I added $100 \mu \mathrm{L}$ of DCFH-da and DMEM solution to each well and waited again for 30 min, then measured the fluorescence of the samples, indicating the antioxidant potential in the cells.

\section{Results}

\subsection{Antioxidant Content of Rosemary Extracts}

The concentrations of the standard solutions and the absorbance gave us a proportional equation with which we could calculate the concentration of antioxidants in the extracts, which are equivalent to the corresponding concentration of GAE.

$$
\mathrm{A}=3.406 \times \mathbb{7}(\mathrm{GAE})-0.2486
$$

In the extract obtained after 5 cycles, the GA concentration is $0.433 \mathrm{~g} / \mathrm{L}$.

In $120 \mathrm{~mL}$ of ethanol extract: $m(\mathrm{GAE})=\mathbb{\gamma}(\mathrm{GAE}) \times$ $V=0.433 \mathrm{mg} / \mathrm{mL} \times 120 \mathrm{~mL}=52 \mathrm{mg}$.

The extract was made from $7.65 \mathrm{~g}$ of dried rosemary. Let us assume that we extract all the polyphenols, then we get: $52 \mathrm{mg}$ (GAE) $/ 7.65 \mathrm{~g}$ rosemary $=6.8 \mathrm{mg} / \mathrm{g}$.

The results clearly show that the more cycles are carried out in a Soxhlet apparatus, the higher the content of antioxidants is in the extract. The highest concentration of antioxidants is contained in rosemary extract from North Macedonia, probably because the sun is the highest in the area, which is very good for the growth of the rosemary.

\subsection{Antioxidant Potential inside the Cells}

From these results we can see that in $5 \%$ and $1 \%$ of the extract from Macedonia, the fluorescence is the highest, which means that it is expected to have the greatest effect on MCF-7 cells or maximum antioxidant potential and consequently less ROS (Fig. 13 Comparison of antioxidant content of rosemary (Rosmarinus oficinalis) from different countries after the fifth Soxhlet extraction cycle).

I measured low fluorescences at $0.1 \%$ of the extracts, the differences between them are small, not necessarily due to the influence of the extracts, but also to other substances in the mixture.

Table 2 Antioxidant concentration in the rosemary extract from North Macedonia.

\begin{tabular}{lll}
\hline Cycle & $\mathrm{A}$ & $\begin{array}{l}\gamma(\mathrm{GAE}) \\
\mathrm{g} / \mathrm{L}\end{array}$ \\
\hline 1 & 0.587 & 0.245 \\
2 & 0.709 & 0.281 \\
3 & 0.810 & 0.311 \\
4 & 1.110 & 0.399 \\
5 & 1.225 & 0.433 \\
\hline
\end{tabular}

Table 3 Antioxidant concentration of the rosemary extract from Greece.

\begin{tabular}{lll}
\hline Cycle & $\mathrm{A}$ & $\begin{array}{l}\mathrm{c}(\mathrm{GAE}) \\
\mathrm{mg} / \mathrm{g}\end{array}$ \\
\hline 1 & 0.337 & 0.172 \\
2 & 0.460 & 0.208 \\
3 & 0.490 & 0.217 \\
4 & 0.570 & 0.240 \\
5 & 0.670 & 0.270 \\
\hline$m(\mathrm{GAE})=\mathbb{V}(\mathrm{GAE}) \times V=0.270 \mathrm{mg} / \mathrm{mL} \times 120 \mathrm{~mL}=32.4 \mathrm{mg} ;$ \\
$32.4 \mathrm{mg}(\mathrm{GAE}) / 7.65 \mathrm{~g}$ rosemary $=4.2 \mathrm{mg} / \mathrm{g}$.
\end{tabular}

Table 4 Antioxidant concentration of the rosemary extract from Slovenia.

\begin{tabular}{lll}
\hline Cycle & $\mathrm{A}$ & $\begin{array}{l}\mathrm{c}(\mathrm{GAE}) \\
\mathrm{mg} / \mathrm{g}\end{array}$ \\
\hline 5 & 0.660 & 0.267 \\
\hline
\end{tabular}

$m(\mathrm{GAE})=\not \gamma(\mathrm{GAE}) \times V=0.267 \mathrm{mg} / \mathrm{mL} \times 120 \mathrm{~mL}=32.04 \mathrm{mg}$; $32.04 \mathrm{mg}(\mathrm{GAE}) / 7.65 \mathrm{~g}$ rosemary $=4.2 \mathrm{mg} / \mathrm{g}$. 


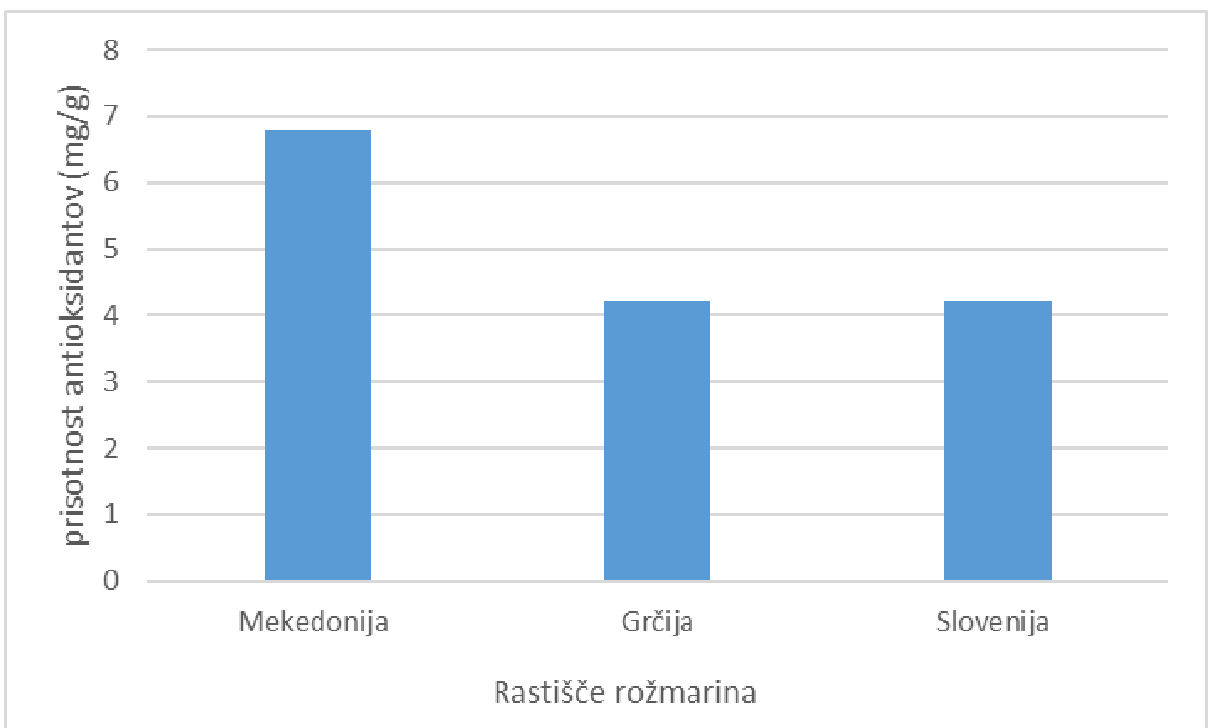

Fig. 13 Comparison of antioxidant content of rosemary (Rosmarinus oficinalis) from different countries after the fifth Soxhlet extraction cycle.

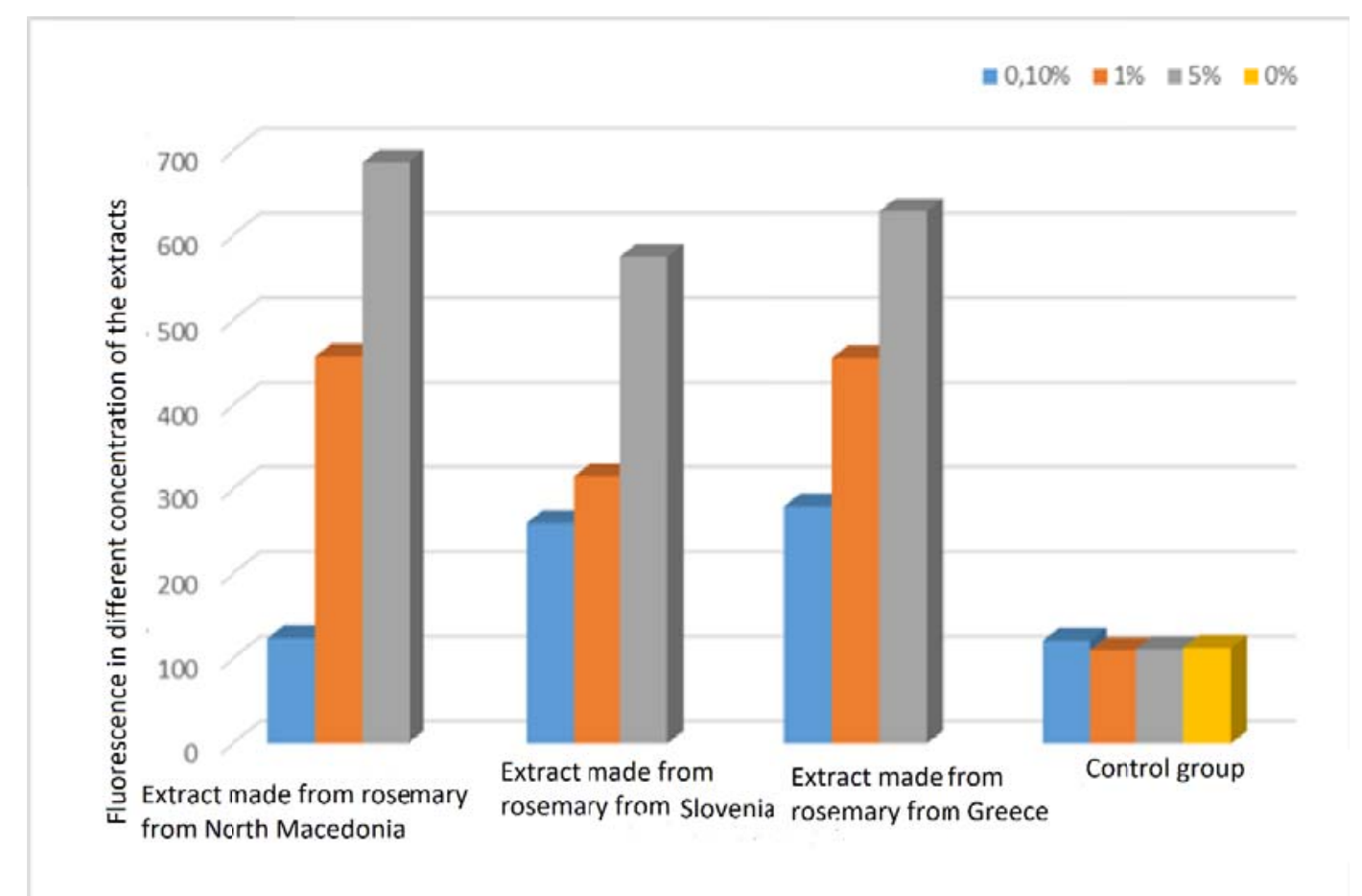

Fig. 14 Fluorescence at different concentrations of rosemary extracts.

\section{Discussion}

Based on the results, I can evaluate my hypotheses and see that the first one is wrong.

(1) Rosemary (Rosmarinus officinalis), which I harvested in Greece on the shores of the Aegean Sea, contains the most antioxidants.
Measurements have shown that the most antioxidants in rosemary are from Macedonia (Table 2). The antioxidant content is influenced by many factors, along with the characteristics of the habitat, the genetic record of the plant itself. Further research should be done to verify these factors.

The second hypothesis was: 
(2) In preparing the ethanol extract of rosemary in the Soxhlet apparatus, 5 cycles will be sufficient.

The hypothesis was correct.

The concentration of antioxidants in extracts (GAE) is expected to increase from the first to the fifth cycle, but there is no longer a significant difference between the fourth and fifth cycles. Further cycles would be uneconomical, especially from an energy point of view.

The third hypothesis was:

(3) The extract with the highest content of phenols and polyphenols has the highest antioxidant potential in MCF-7 cells.

If we compare the results, we see that the hypothesis is correct. The highest antioxidant potential was measured with a 5\% extract from Macedonia which also has the highest concentration of phenols and polyphenols (GAE).

At lower concentrations of extracts in cells, however, there is no such clear correlation between the antioxidant potential of extracts and the concentration of phenols and polyphenols in them.

\section{Conclusion}

The aim of the research was to demonstrate the anti-cancer effect of rosemary extracts. Using spectrophotometry method, I have found that most of the total phenols contain the rosemary extract from Macedonia.

I analyzed the antioxidant potential using the DCFH method (Fig. 14).

The analysis of the results also showed that the plant with the most antioxidants had the best effect on the cells, that is, most ROS react.

The field of study of the medicinal effects of rosemary is still largely unexplored. Nevertheless, many studies provide us with encouraging results that indicate the positive effects of phenolic compounds of rosemary in the medical field.

The research mission opens a new perspective on the already confirmed practice rosemary health benefits that rosemary certainly helps us and that we should definitely continue exploring these fields.

\section{Social Awareness}

In preparing my research assignment, I followed the basic principles of social responsibility. With it I wanted to point out the solutions that nature offers us. The common rosemary plant, Rosmarinus officinalis, has many healing effects from improving digestion, reducing stress, increasing memory and concentration. Recently, its anti-cancer properties, its ability to protect against macular degeneration, and the rest (etc.) have also been discovered in this modern world when the incidence rate of cancer is more and more increasing. While being interested in the problem of increasing the number of cancers in the modern world, it seemed important to me to add a bit of knowledge in developing successful treatment methods based on helpful products already present in the plant world.

\section{Acknowledgement}

I sincerely thank all the people who helped me do this research. I also thank the doctor who gave me access to a laboratory at the University of Maribor Faculty of Medicine in which we were growing MCF-7 cells and then checked the effect of extracts on them.

\section{References}

[1] Topolovec, S. Rožmarin. Farmedica. Available at: https://www.farmedica.si/rastlina/52/Rozmarin.

[2] Probotanic. [s.d.]. Available at: https://www.probotanic.com/sl/informacije-sl/olje-rozmar ina/.

[3] Desaulniers, D. V. 2016. "Rosemary Helps Heal Estrogen-Dominant Breast Cancer." Available at: https://www.naturalhealth365.com/rosemary-breast-cance r-estrogen-1704.html.

[4] MCF-7 Cells. 2017. MCF-7. Available at: http://www.mcf7.com/.

[5] Jacobs, B. E. M. 1981. United States: 4. 1. 1981. Available at:

https://www.amazon.com/Growing-Using-Herbs-Success fully-Garden/dp/088266249.

[6] Azwanida, N. N. 2015. Newcastle University. Available at: https://www.omicsonline.org/open-access/a-review-on-th 
e-extraction-methods-use-in-medicinal-plants-principle-st rength-and-limitation-2167-0412-1000196.php?aid=5844 8.

[7] Kaefer, C. M., and Milner, J. A. 2011. Available at: https://www.ncbi.nlm.nih.gov/books/NBK92774/.

[8] Abramović, I. 2013. "Določevanje stabilnosti nekaterih polifenolnih antioksidantov." Available at: http://pefprints.pef.uni-lj.si/1596/1/Diplomska_naloga-Ire na_Abramovic.pdf.

[9] Lesjak, K. 2009. Gojenje Celic Elastičnega Hrustanca Za Uporabo V Tkivnem Inženirstvu. Ljubljana. Available at: https://docs.google.com/document/d/1vPFKxuF23791P6 KBFRa7kzkQkCtwNYfGJntN941x6HE/edit.

[10] Cheung, S., and Tai, J. 2007. "Anti-proliferative and Antioxidant Properties of Rosemary Rosmarinus officinalis." Available at: https://pdfs.semanticscholar.org/0288/eb094820582b053f 73c8d6e0dde1f1edd46f.pdf.

[11] MCF-7. 2018. Wikipedia, the free encyclopedia. Available at: https://en.wikipedia.org/wiki/MCF-7.

[12] Kulevanova Svetlana, D. S. 2016. ПрактикумпопредметотФитохемија. Skopje.

[13] Englesko-hrvatskikemijskirječnik\&glosar. 29. 122018. Available https:/glossary.periodni.com/glosar.php?hr=spektrofoto metrija.

[14] Pivk, B. 2011. Instrumentalnemetodeprianaliznikemijji. Available at: http://www.ssfkz.si/datoteke/elektronska_gradiva/Inst_m
etode_v_analizni_kemiji/Inst_metode_v_analizni_kemiji. pdf.

[15] Agbor, G. J. V. 2014. "Folin-Ciocalteau Reagent for Polyphenolic Assay." Available at: https://scidoc.org/IJFS-2326-3350-03-801.php.

[16] Folin-Cioucalteu Reagent. 2018. Wikipedia, the free encyclopedia. Available at: https://en.wikipedia.org/wiki/Folin\%E2\%80\%93Ciocalte u_reagent.

[17] SpectroVis Plus User Manual. Vernier. [s.d.]. Available at: https://www.vernier.com/manuals/svis-pl/.

[18] DMEM/F-12. [s.d.]. Thermo Fisher Scientific. Available at:

https://www.thermofisher.com/order/catalog/product/113 20033.

[19] Burtis, C. A. E. R. 2012. Clinical Chemistry and Molecular Diagnostics, 5th ed. Riverport Lane St. Louis, Missouri. ISBN 978-1-4160-6164-9.

[20] Fetal Bovine Serum. Biological Industries. Available at: http://knj.gcc.si/files/2012/10/KIZ-Navajanje-virov-in-lit erature.pdf.

[21] Kandashvili, M. 2018. "What Is the Trypsin Mechanism in Cell Culture." Research Gate. Available at: https://www.researchgate.net/post/What_is_the_trypsin_ mechanism_in_cell_culture.

[22] Ritter, J., Flower, R., Henderson, G., and Rang, H. 2015. Rang \& Dale's Pharmacology, 8th ed. Churchill Livingstone. 